\title{
Modeling of environmental aspects related to reverse osmosis desalination supply chain
}

\author{
Mohammad Reza Mehrgan $^{1^{\circledR}}$, Hannan Amoozad Mahdiraji $^{\circledR}$, Shahab Binaee $^{2^{*} \oplus}$, Vali Alipour ${ }^{*}{ }^{\circledR}$, \\ Seyyed Hossein Razavi Haji Agha ${ }^{\circledR}$ \\ ${ }^{1}$ Department of Industrial Management, Faculty of Management, University of Tehran, Tehran, Iran \\ ${ }^{2}$ Operations management department, Kish international Kampus, University of Tehran, Kish Island, Iran, \\ ${ }^{3}$ Department of Environmental Health Engineering, School of Health, Hormozgan University of Medical Sciences, Iran \\ ${ }^{4}$ Department of Management, Khatam University, Tehran, Iran
}

\begin{abstract}
Background: This study aimed to model optimization of strategic environmental management decisions in the operation of reverse osmosis desalination, emphasizing the costs required for the environmental protection during the production of freshwater using reverse osmosis technology.

Methods: This analytical research was conducted in five cities of Hormozgan province in Iran for 18 months from February 2018 to September 2019. The research includes eight phases of defining the research problem, data collection, preliminary data analysis and decision criteria, mathematical modeling, model validation, information preparation, analysis and finally discussion, conclusions and suggestions. The main environmental issues were the carbon dioxide $\left(\mathrm{CO}_{2}\right)$ release rate due to power demand and rejected brine water (RBW) were entered the mathematical model.

Results: The desalination plants of Abu Musa, Bandar Abbas, Qeshm, Sirik, and Hormoz with water production flow rate of $2100,89000,5300,3300$ and $1500 \mathrm{~m}^{3} / \mathrm{d}$ can generate $2360.82,100053.80$, $5958.260,3709.86$ and 1686.30 tons/year of $\mathrm{CO}_{2}$ emissions respectively. This output requires 1.35, 57.47, $3.42,2.13$ and 0.97 million USD for controlling the process, respectively. For reduction of the negative effect of RBW $0.75,22.79,1.78,1.15$ and 0.55 million USD respectively, is needed.

Conclusion: Recommendations for environmental impacts protection of RBW, for desalination capacity up to $50000 \mathrm{~m}^{3} / \mathrm{d}$, are; (a) for desalination capacity up to $50000 \mathrm{~m}^{3} / \mathrm{d}$; dilution the RBW using raw water before entering into the sea, (b) for capacity of 50 000-100 $000 \mathrm{~m}^{3} / \mathrm{d}$; dispersing RBW in sea using diffuser, and (c) for capacity more than $100000 \mathrm{~m}^{3} / \mathrm{d}$; hybrid water desalination plants and power plant. Application of power plant cooling water to dilute RBW may reduce cost.

Keywords: Mathematical modeling, Freshwater, Osmosis, Brine, Seawater.

Citation: Mehrgan MR, Mahdiraji HA, Binaee S, Alipour V, Razavi Haji Agha SH. Modeling of environmental aspects related to reverse osmosis desalination supply chain. Environmental Health Engineering and Management Journal 2020; 7(1): 31-40. doi: 10.34172/EHEM.2020.05.
\end{abstract}

\section{Article History:}

Received: 24 September 2019

Accepted: 2 February 2020

ePublished: 29 February 2020

\section{Introduction}

Although water accounts for about $71 \%$ of the earth surface, freshwater scarcity is one of the most important worldwide issues. Oceans and seas contain about $97.5 \%$ of total water, while freshwater is only $2.5 \%$, of the total, more than $68 \%$ is locked up in polar ice and glaciers, and the rest " $30 \%$ " is groundwater (1). Iran's renewable water resources are estimated to be 110 to 130 billion cubic meters per year. With a population of more than 80 million, the country's per capita renewable water is less than 1700 cubic meters per year. With any of the internationally accepted indices, Iran is in the state of water stress and dehydration which necessitates the use of desalination.
The worldwide capacity for desalination projects increased dramatically from 326 cubic meters per day in 1945 to more than 95.6 million cubic meters per day in 2016 (2). Among the existing desalination technologies, reverse osmosis membrane technology accounts for $66 \%$ of the capacity utilized, followed by multi-stage flash and multi-effect distillation with $20 \%$ and $7 \%$ of the capacity utilized, respectively (3). Seawater accounts for $58 \%$ of the world's desalination water feed (4).

Environmental impacts of seawater reverse osmosis (SWRO) desalination can be broadly classified into three categories, including energy consumption which releases carbon dioxide $\left(\mathrm{CO}_{2}\right)$ into the atmosphere, intake and 
brine discharge $(5,6)$. Desalination effluent results in known environmental effects on seagrass habitats and phytoplankton, invertebrates and fish communities in areas surrounding effluent discharge $(7,8)$. Overall, enclosed and shallow sites with abundant marine organisms are more sensitive to effluent discharge than the offshore sites capable of diluting and dispersing plant rejected water $(2,9)$.

The previous studies have shown the variable effects of desalination plants on the salinity of the received water. Based on the studies, the effects of saline effluent discharge can be observed for tens or hundreds of meters $(10,11)$, or in extreme cases, several kilometers from the effluent discharge site (12). Few studies on the environmental issues of intake and brine discharge of SWRO, have shown that proper design of SWRO based on the environmental impact analysis, can minimize the environmental impacts and the costs of environmental protection for desalination plants were analyzed (5,13-16).

Most of theabove-mentioned modelsfocused on optimizing the economic dimension of water supply systems and often overlook the details of the environmental aspects. This research expanded the economic model presented by Al-Nory et al (17) regarding the water supply chain of the desalination plant by emphasizing environmental details. Environmental details include modeling the reduction of salinity and chemical components of the rejected brine water (RBW) from plants by diluting the effluent before being entered the sea according to a standard that permits discharge into the receiving water. Note that, $\mathrm{CO}_{2}$ emissions have also been modeled as an environmental impact. Desalination supply chain activities include obtaining feed water and chemicals needed for the desalination processes, desalination process systems, water storage and distribution of freshwater to endusers (18). The importance of examining the economic and environmental impacts of water purification using desalination technology and the provision of desalinated water allows decision-makers to examine the system as a whole (19). For instance, any delay in the distribution of water from storage tanks to consumers could disrupt the desalination process and affect the overall performance of the desalination water supply chain. In this study, due to the importance of environmental issues in terms of produced water costs and environmental protection aspects, this subject is evaluated and modeled in Hormozgan province as the center of the desalination of Iran.

\section{Materials and Methods}

This analytical research is conducted in 5 cities of Bandar Abbas, Qeshm, Hormoz, Sirik, and Abu Musa in Hormozgan province (Figure 1) for 18 months from February 2018 to September 2019. In addition, the operational and environmental data of desalination plants for a period of past 20 years were obtained from the Hormozgan Water and Wastewater Company; then

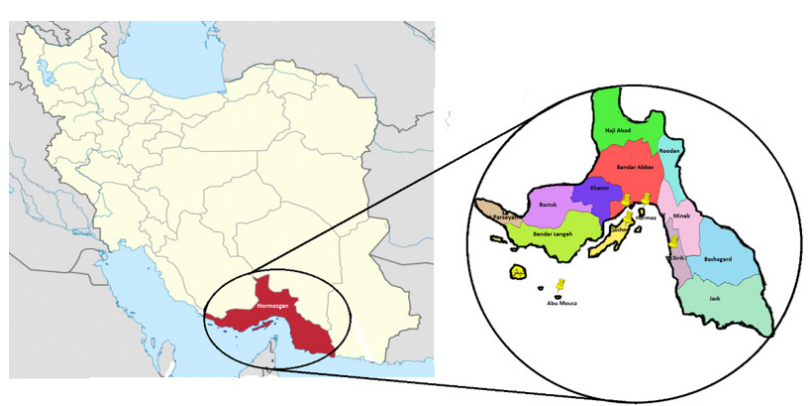

Figure 1. The locations of studied desalination plants.

entered in the model and analyzed.

The study plan was classified into eight phases encompassing: 1) Defining research problem, 2) Data collection, 3) Preliminary data analysis and decision criteria, 4) Mathematical modeling, (5) Model validation, 6) Information preparation, 7) analysis and 8) Discussion, Conclusions and suggestions.

In the present study, the typical SWRO plants are studied. The main parts of typical SWRO plants are included in the Intake section, pretreatment (generally coagulation and granular filter), high-pressure pumps and membrane modules. After that, a post-treatment unit is located to add some minerals to the $\mathrm{RO}$ water product (Figure 2). Modeling fundamental data include the rate of raw water intake, water production, and brine water flow rate, type of discharge into receiving waters, and investment cost and operating costs such as the consumed power used chemicals, manpower, and the other economic and environmental aspects.

To evaluate the $\mathrm{CO}_{2}$ production, since the power generation model in Iran is almost similar to the water production by desalination, the mathematical model of electricity production in Iran is used to estimate the amount of $\mathrm{CO}_{2}$ emitted from desalination plants $(20,21)$ Since the power generation model in Iran is almost similar to the Portuguese power generation model collected from the literature (21), this model was used to estimate the amount of greenhouse gas $\mathrm{CO} 2$ required by the mathematical model.

\section{Model parameters}

In this analysis, a mathematical model is employed which its parameters are shown in Table 1. Note that the model is based on AL-Nory et al (17) and Balfaqih et al (1).

Decision variables

Decision variables for the production and investment in desalination plants and transmission lines presented in Table 2.

The total cost of water (TWC) is often cited in the literature of the desalination industry as a common comparison between projects. Table 3 shows comparative evaluation of the total cost of the objective functions and their components per cubic meter of freshwater. 


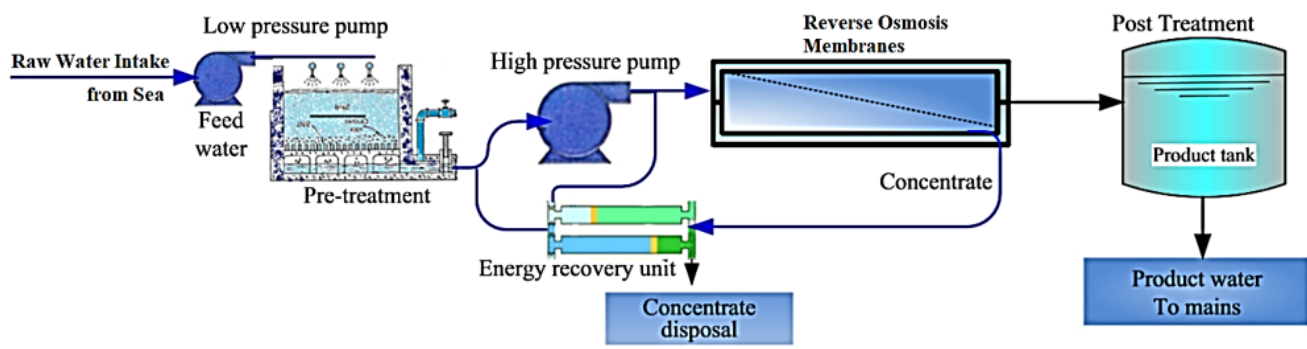

Figure 2. Simple diagram of a typical reverse osmosis desalination plant (20)

Target function optimization

The objective function specified in Eq (1), minimizes the total investment cost and supply chain operation of both the plant and the transmission line. Furthermore, it minimizes environmental impacts.

$$
\operatorname{minTC}=\sum_{l \in N^{S}} c_{l}^{T}+c_{l}^{e n v i T}+\sum_{i \in E} c_{i}^{N}
$$

Model limitations

The model has a few limitations. Equation (2) represents the net present value (NPV) of the total investment cost
(CAPEX) of the plant at the location (l).

$$
v_{l}^{c}=\sum_{t \in T_{l}} \frac{c p x_{l t}^{T} * y_{l t}}{(1+i n t)} \quad \forall \quad \mathrm{l} \in \mathrm{Ns}
$$

Equation (3) represents the NPV of the operation cost at the location (l) in the time of (h).

$$
v_{l h}^{o}=\sum_{t \in T_{l}} \frac{o p x_{l t}^{T} *(1+\mathrm{inf})^{h} * x_{l t h}}{(1+i n t)^{h}} \quad \forall \quad l \in \mathrm{Ns}, \mathrm{h} \in \mathrm{H}
$$

\begin{tabular}{|c|c|}
\hline Parameter & Definition \\
\hline Inf & Inflation rate \\
\hline Int & Interest rate \\
\hline $\mathrm{cpx}_{\text {It }}^{\top}$ & Estimation of investment cost for factory $(\mathrm{t})$ at location $(\mathrm{I})$ at time $(0)$ \\
\hline $\mathrm{v}_{\mathrm{lh}}^{\circ}$ & Net present value (NPV) of the total operating costs (OPEX) of the factory $(\mathrm{t})$ at the location $(\mathrm{I})$ in time horizon $(\mathrm{h})$ \\
\hline $\operatorname{aopx}_{\mathrm{lt}}^{\top}$ & Estimation of annual operating costs of plant $(t)$ at location (I) \\
\hline $\mathrm{opx}_{\mathrm{It}}^{\top}$ & Estimation of the first-year operating costs for each cubic meter of a desalination plant at the location (I) \\
\hline$v_{1}^{r}$ & The value of the plant's rotation at the location $(\mathrm{I})$ at the end of the planning period \\
\hline $\mathrm{cpx}_{\mathrm{i}}^{\mathrm{N}}$ & Estimated the total investment costs per year for each transmission line (i) \\
\hline $\mathrm{W}_{\text {ih }}^{\circ}$ & NPV total operating costs in the year of zero (OPEX) in Network time of $(\mathrm{h})$ \\
\hline $\operatorname{aopx}_{\mathrm{i}}^{\mathrm{N}}$ & Annual operating cost estimates (OPEX) at transmission line (i) \\
\hline$o p x_{i}^{N}$ & Estimation of the first-year operating costs per cubic meter of water at transmission line (i) \\
\hline $\operatorname{cap}_{t}^{\top}$ & Desalination plant design capacity $\left(\mathrm{m}^{3} / \mathrm{d}\right) \mathrm{t} \in \mathrm{T}$ \\
\hline $\operatorname{cap}_{\mathrm{i}}^{\mathrm{N}}$ & Transmission line capacity $\left(\mathrm{m}^{3} / \mathrm{d}\right) \mathrm{i} \in \mathrm{E}$ \\
\hline $\mathrm{E}_{1}^{\mathrm{s}}$ & Plant Outlet Pipe Set $\mathrm{I} \in \mathrm{N}^{\mathrm{s}}$ \\
\hline $\mathrm{E}^{\mathrm{in}}$, & The sum of input influents to the aggregator in place $I \in \mathrm{N}^{a}$ \\
\hline Eout & The output stream of the collector at the location $I \in N^{a}$ \\
\hline $\mathrm{d}_{\mathrm{Ih}}$ & Demand in place $I \in N^{d}$ at the time of $(h)$ \\
\hline $\mathrm{cf}_{\text {Ith }}$ & Plant capacity $t \in T_{1}$ at the location $\mathrm{I} \in \mathrm{N}^{\mathrm{s}}$ at the time of $\mathrm{h} \in \mathrm{H}$ \\
\hline $\mathrm{u}_{\mathrm{it}}^{\mathrm{co2}}$ & $\mathrm{CO}_{2}$ emissions produced by the plant $(\mathrm{t})$ at the location $(\mathrm{I})$ for one cubic meter of water $\left(\mathrm{Kg} \mathrm{CO}_{2} / \mathrm{m}^{3}\right)$ \\
\hline $\mathrm{Er}_{\text {It }}$ & Power required by the plant $(\mathrm{t})$ in $\left(\mathrm{kwh} / \mathrm{m}^{3}\right)$ \\
\hline Ef & $\mathrm{CO}_{2}$ emission factor $\left(\mathrm{CO}_{2} \mathrm{~kg}-\mathrm{e} / \mathrm{kwh}\right)$ \\
\hline opx $\mathrm{CO}_{2}$ & $\mathrm{CO}_{2} \operatorname{cost}\left(\$ / \mathrm{kg} \mathrm{CO}_{2}\right)$ \\
\hline Pc & The $v_{1}^{c}$ coefficient as the percentage of the total investment cost for the effluent dilution cost \\
\hline Po & The $v_{\mathrm{Ih}}{ }^{\circ}$ coefficient as the percentage of the total investment cost for the effluent dilution cost \\
\hline
\end{tabular}

Table 1. Mathematical model parameters used in the study 
Table 2. Decision variables for the production and investment in desalination plants and transmission line

\begin{tabular}{|c|c|}
\hline Decision Variables & Description \\
\hline XIth & The rate of produced water in the plant at the location $(\mathrm{I})$ at time of $(\mathrm{h})$ whenever $\mathrm{I} \in \mathrm{Ns}$ ، $\mathrm{t} \in \mathrm{Tl}$ and $\mathrm{h} \in \mathrm{H}$; except year (0) \\
\hline Ylt & The number of $(\mathrm{t})$ plants installed at the location (I) whenever $\mathrm{t} \in \mathrm{TI}, \mathrm{I} \in \mathrm{Ns}$ \\
\hline Zih & The current rate in the transmission line (i) at the time (h) whenever $\mathrm{i} \in \mathrm{E}$ and $\mathrm{h} \in \mathrm{H}$ \\
\hline $\mathrm{Vcl}$ & Net present value (NPV) of the total investment costs (CAPEX) for the plant at the location (I) \\
\hline cTl & NPV of the total plant costs at the location (I) \\
\hline Wci & NPV of the total investment costs (CAPEX) at water transmission line \\
\hline $\mathrm{cNi}$ & NPV of the total transmission line cost (i) \\
\hline ulCO2 & Total emissions of $\mathrm{CO}_{2}$ at the location (I) per year \\
\hline $\mathrm{Opxul} \mathrm{CO}_{2}$ & NPV of the total costs of $\mathrm{CO} 2$ emission at the location (I) \\
\hline Clred TDS \&chem & NPV of the total effluent dilution costs to reduce TDS and effluent chemical concentrations \\
\hline clenviT & NPV of the total environmental costs of the desalination plant at the location (I) \\
\hline
\end{tabular}

Equation (4) represents the NPV of the residual value of the plant at the location (l) at the end of the design period.

$$
v_{l}^{r}=\sum_{t=T_{l}} \frac{n d p_{l t} *(1+i n f)^{|H|+2} * y_{l t}}{(1+i n t)^{|H|+2}} \quad \forall \mathrm{l} \in \mathrm{Ns}
$$

Equation (5) represents the NPV of the total cost of the plant at the location (l).

$c_{l}^{T}=v_{l}^{c}+\sum_{h \in H} v_{l h}^{o}-v_{l}^{r} \quad \forall \quad l \in \mathrm{N}^{\mathrm{s}}$

Equation (6) represents the NPV of the total investment cost (CAPEX) of the transmission line at the location (1).

$$
w_{i}^{c}=\frac{c p x_{i}^{N}}{(1+i n t)} \quad \forall \quad \mathrm{i} \in \mathrm{E}
$$

Equation (7) represents the NPV of the total operational costs (OPEX) for the transmission line at time (h).

$w_{i h}^{o}=\frac{o p x_{i}^{N} *(1+i n f)^{h} * z_{i h}}{(1+i n t)^{h}} \quad \forall \mathrm{i} \in \mathrm{E}$

Equation (8) represents the NPV of the total costs for the transmission line.

$c_{i}^{N}=w_{i}^{c}+\sum_{h \in H} w_{i h}^{o} \quad \forall \mathrm{i} \in \mathrm{E}$

The binary variable is the establishment or nonestablishment of the plant as Eq (9). Moreover, the binary variable is the establishment or non-establishment of the transmission line as Eq (10).

$\mathrm{Y}_{\mathrm{t}}=0$ or $1(9)$

$\mathrm{Y}_{\mathrm{i}}=0$ or $1(10)$

Equation (11) shows the water produced rate by the plant (t) at the location (l) in the time horizon (h) limited by the plant capacity at the location (l) with the $\mathrm{cfl}_{\text {th }}$ capacity coefficient.

$x_{l t h} \leq \operatorname{cap}_{t}^{T} * c f_{l t h} * 365 * y_{l t} \forall \quad \mathrm{l} \in \mathrm{Ns}, \mathrm{t} \in \mathrm{Tl}, \mathrm{h} \in \mathrm{H}$

Equation (12) denotes the amount of freshwater that responds to the locations water demand at location (l) in the time period $(\mathrm{h})$, which is equal to or greater than the demand.

$\sum_{i \in E_{l}^{d}} z_{i h} \geq d_{l h} \quad \forall \quad l \in \mathrm{Nd}, \mathrm{h} \in \mathrm{H}$

Equation (13) shows the amount of fresh water entered into and out of the aggregator; input amount is equal to the output.

$\sum_{i \in E_{l}^{\text {in }}} Z_{\text {ih }}=\sum_{i \in E_{l}^{\text {out }} Z_{i h}} \quad \forall \quad l \in \mathrm{N}^{\mathrm{a}}, \mathrm{h} \in \mathrm{H}$

The total amount of water produced by the desalination plant $(\mathrm{t})$ at the location (l) enters the transmission line according to Eq (14).

$\sum_{t \in T_{l}} x_{l t h}=\sum_{i \in E_{l}^{s}} z_{i h} \quad \forall \quad \mathrm{l} \in \mathrm{Ns}, \mathrm{h} \in \mathrm{H}$

The flow rate of water at the transmission line (i) at the time (h) is limited to the capacity of the transmission line (i) and is as Eq (15).

$z_{i h} \leq \operatorname{cap}_{i}^{N} \quad \forall \quad \mathrm{i} \in \mathrm{E}, \mathrm{h} \in \mathrm{H}$

The $\mathrm{CO}_{2}$ emission value of the desalination does not exceed the emission limit for $\mathrm{CO}_{2}$ emissions and is as Eq (16).

$u \leq u^{\max }$

The total amount of $\mathrm{CO} 2$ emissions at the location (1) is as $\mathrm{Eq}(17)$. 
$u_{l}^{C O_{2}}=\sum_{t \in T_{l}} x_{l t h} * u_{l t}^{C O_{2}} \quad \forall \quad l \in \mathrm{N}^{\mathrm{s}}$

The $u^{c o 2}{ }_{l t}, \mathrm{CO}_{2}$ emissions produced by the plant ( $\mathrm{t}$ ) at the location (l) for one cubic meter of water is as Eq (18).

$u_{l t}^{C O_{2}}=E r_{l t} * E f$

Where $\mathrm{Er}_{\mathrm{lt}}$ is the energy required by the $(\mathrm{t})$ plant $\mathrm{kWh} /$ $\mathrm{m}^{3}$ and $\mathrm{Ef}$ is the $\mathrm{CO}_{2}$ emission factor $\left(\mathrm{kg} \mathrm{CO}_{2}-\mathrm{e} / \mathrm{kWh}\right)$. The NPV of the total cost of $\mathrm{CO}_{2}$ emissions in the period design is $(\mathrm{H})$ and is as $\mathrm{Eq}(19)$.

$$
{ }_{o p x u} \mathrm{CO}_{l}=\sum_{h \in H} \frac{u_{l}^{\mathrm{CO}_{2}} \times o p x C O_{2} \times(1+i n f)^{h}}{(1+i n t)^{h}}
$$

The opx $\mathrm{CO}_{2}$ is the cost of $\mathrm{CO}_{2}$ in $\$ / \mathrm{kg} \mathrm{CO}_{2}$. The NPV is the cost of diluting the brine discharge to reduce the salinity and effluent chemicals is as Eq (20).

$c_{l}^{\text {redTDS\&chem }}=p c \times v_{l}^{c}+p o \times \sum_{h \in H} v_{l h}^{o}$

The NPV is the total cost of reducing the environmental impacts of the desalination plant which is expressed in Eq (21).

$c_{l}^{\text {enviT }}=o p x u_{l}^{\mathrm{CO}_{2}}+c_{l}^{\text {redTDS\&chem }}$

The cost of operating one cubic meter of water at the $\mathrm{opx}_{\mathrm{lt}}{ }^{\mathrm{T}}$ plant is presented in Eq (22).

$$
o p x_{l t}^{T}=\frac{a o p x_{l t}^{T}}{c a p_{t}^{T} \times c f_{l t h} \times 365}
$$

Remark that the capacity of the cap ${ }^{\mathrm{T}}$ plant is expressed as $\mathrm{m}^{3} / \mathrm{d}$. The coefficient capacity of $\mathrm{cf}_{\text {lth }}$ is considered for the plant of $t \in T_{1}$ at the location of $l \in \mathrm{N}^{s}$ at time $h \in H$. The estimation of the $\mathrm{opx}_{\mathrm{i}}^{\mathrm{N}}$ operating costs per cubic meter of water in the transmission line $\mathrm{i}$ is as $\mathrm{Eq}(23)$.

$$
o p x_{i}^{N}=\frac{a o p x_{i}^{N}}{\operatorname{cap}_{i}^{N} * 365}
$$

Remark that the capacity of the transmission line $\operatorname{cap}_{i}{ }^{\mathrm{N}}$ is expressed as $\mathrm{m}^{3} / \mathrm{d}$. The total cost of the water supply chain (TWC) for comparing the objective functions and its components per cubic meter of freshwater is as follows. To make the target functions understandable and comparable, it is expressed in terms of TWC, the total cost per cubic meter of freshwater $\left(\mathrm{US} \$ / \mathrm{m}^{3}\right)$.

TWC $_{1}$ plant. Total Investment, operation and environmental costs (Salinity Reduction $+\mathrm{CO}_{2}$ ) as US\$/ $\mathrm{m}^{3}$ of freshwater as Eq (24).
$T W C_{1}=\frac{\sum_{l \in N^{s}} c_{l}^{T}+c_{l}^{e n v i T}}{\sum_{h \in H} x_{l t h}}$

TWC $_{2}$ plant. Total Investment, operating and environmental costs (for the salinity reduction) without $\mathrm{CO}_{2}$ control cost as $\mathrm{US} \$ / \mathrm{m}^{3}$ of freshwater as Eq (25).

$T W C_{2}=\frac{\sum_{l \in N^{s}} c_{l}^{T}+c_{l}^{\text {redTDS\&chem }}}{\sum_{h \in H} x_{l t h}}$

TWC $_{3}$ plant. Total investment and operating, without environmental costs as US $\$ / \mathrm{m}^{3}$ of fresh water is as $\mathrm{Eq}(26)$.

$$
T W C_{3}=\frac{\sum_{l \in N^{s}} c_{l}^{T}}{\sum_{h \in H} x_{l t h}}
$$

TWC $_{4}$ for transmission line. Total investment and operating costs as US\$ $/ \mathrm{m}^{3}$ of fresh water is as Eq (27).

$T W C_{4}=\frac{\sum_{i \in E} c_{i}^{N}}{\sum_{h \in H} x_{l t h}}$

TWC5 for plant plus transmission line. Total investment, operating and environmental costs (salinity+ $\mathrm{CO}_{2}$ ) in $\mathrm{US} \$ / \mathrm{m}^{3}$ per cubic meter of freshwater as Eq (28).

$T W C_{5}=\frac{\min T C}{\sum_{h \in H} x_{l t h}}$

TWC6 for plant plus transmission line. Total investment, operating and environmental costs (salinity reduction) without $\mathrm{CO}_{2}$ control in $\mathrm{US} \$ / \mathrm{m}^{3}$ per cubic meter of freshwater is as Eq (29).

$T W C_{6}=\frac{\sum_{l \in N^{s}} c_{l}^{T}+c_{l}^{\text {redTDS\&chem }}+\sum_{i \in E} c_{i}^{N}}{\sum_{h \in H} x_{l t h}}$

TWC7 for plant plus transmission line. Total investment and operating without environmental costs in US $\$ / \mathrm{m}^{3}$ of freshwater is as Eq (30).

$T W C_{7}=\frac{\sum_{l \in N^{S}} c_{l}^{T}+\sum_{i \in E} c_{i}^{N}}{\sum_{h \in H} x_{l t h}}$

TWC8 environmental. The cost of $\left(\mathrm{CO}_{2}+\right.$ salinity reduction) in $\mathrm{US} \$ / \mathrm{m}^{3}$ of fresh water is as $\mathrm{Eq}$ (31).

$T W C_{8}=\frac{\sum_{l \in N^{s}} c_{l}^{e n v i T}}{\sum_{h \in H} x_{l t h}}$

WC9 environmental. The cost $\left(\mathrm{CO}_{2}\right)$ in US $\$ / \mathrm{m}^{3}$ of fresh water is as Eq (32).

$T W C_{9}=\frac{\sum_{l \in N^{s}} o p x u_{l}^{C O_{2}}}{\sum_{h \in H} x_{l t h}}$ 
TWC $_{10}$ environmental. The cost (salinity reduction) in $\mathrm{US} \$ / \mathrm{m}^{3}$ of fresh water is as $\mathrm{Eq}(33)$.

$T W C_{10}=\frac{\sum_{l \in N^{s}} c_{l}^{\text {redTDS\&chem }}}{\sum_{h \in H} x_{l t h}}$

Based on the previous studies, the total cost of a carbon tax was ranging from $\$ 19$ per ton (22) to $\$ 23$ per ton (23). In this study, it is estimated at $\$ 23$ per ton or $\$ 0.023$ per kilogram of $\mathrm{CO}_{2}$. According to the standards of Iran Environmental Protection Agency (EPA), a maximum of $10 \%$ salinity in the receiving water into discharge the effluent is allowed (24). The effluent dilution cost is estimated as a percentage of the total cost of operating and operating for desalination plant. The mathematical model is then coded in MATLAB software and solved using an opti-intlinprog solver from the OPTI Toolbox. By changing the parameters, the sensitivity analysis of the designed model is presented.

\section{Results}

The model for the existing water desalination supply chain in the cities of Abu Musa, Bandar Abbas, Dargan Qeshm, Sirik, and Hormuz is solved based on the data collected during 20 years and presented in Table 3 . The model output decision variables are presented in Table 4. Comparative evaluation of the total cost of objective functions and their components in terms of cubic meters of fresh water is also illustrated in Figure 3.

\section{Discussion}

The function of "environmental target" is investigated in two parts including environmental impacts of $\mathrm{CO}_{2}$ emissions and environmental effects of saline effluent disposal. For desalination supply chain in Bandar Abbas, Total TWC 5, TWC 3, plant, TWC 4, transmission line TWC $9 \mathrm{CO}_{2}$, TWC 10 Wastewater dilution are 0.5334 , $0.3640,0.0458,0.0885$ and $0.0351 \mathrm{US} \$ / \mathrm{m}^{3}$ respectively, presented in Figure 4.

Environmental costs of $\mathrm{CO}_{2}$ emissions control Increased use of fossil fuels for desalination can increase air pollution caused by $\mathrm{CO}_{2}$ emissions and cause damage to public health and the environment. For energy consumption of $4 \mathrm{~kW} / \mathrm{m}^{3}$, the portion of environmental costs related to $\mathrm{CO}_{2}$ emissions is computed by about $16.59 \%$ which equals to $0.0885 \mathrm{US} \$ / \mathrm{m}^{3}$ (Table 5). As shown in Table 6, the Bandar Abbas desalination plant with a nominal and actual capacity of 100000 and 89000 $\mathrm{m}^{3} / \mathrm{d}$ respectively, annually produces $10008800 \mathrm{~kg} \mathrm{CO}$, assuming $4 \mathrm{~kW}$ of energy consumption per a cubic meter fresh water production. Reducing energy consumption leads to a reduction in the amount of $\mathrm{CO}_{2}$. With more efficient utilization and energy recovery, energy can

Table 3. Mathematical model inputs; Interest rate $0 f 18 \%$, Inflation rate of $20 \%$ and time period of 20 year; $\left(\mathrm{Ef}=0.77\left(\mathrm{CO}_{2} \mathrm{~kg}-\mathrm{e} / \mathrm{kWh}\right), \mathrm{cf}_{\mathrm{th}}=0.9, \mathrm{Er}=4 \mathrm{kWh} /\right.$ $\mathrm{m}^{3}$, opx $\mathrm{CO}_{2=} 0.023$ US $\$$ kg CO2, $\left.\mathrm{Pc}=0.15, \mathrm{Po}=0.07\right)$

\begin{tabular}{|c|c|c|c|c|c|c|c|}
\hline \multicolumn{2}{|c|}{ Input parameter } & \multirow{2}{*}{$\frac{\text { Unit }}{\mathrm{M}^{3} / \mathrm{d}}$} & \multirow{2}{*}{$\begin{array}{c}\text { Hormoz } \\
1750\end{array}$} & \multirow{2}{*}{$\begin{array}{c}\text { Sirik } \\
3750\end{array}$} & \multirow{2}{*}{$\frac{\text { Qeshm }}{6000}$} & \multirow{2}{*}{$\frac{\text { Bandar Abbas }}{100000}$} & \multirow{2}{*}{$\begin{array}{c}\text { Abu Musa } \\
2500\end{array}$} \\
\hline \multirow{3}{*}{ Desalination } & $\operatorname{cap}_{t}^{\top}$ & & & & & & \\
\hline & $\mathrm{cpx}_{\mathrm{It}}^{\top}$ & US\$ & 2300000 & 4500000 & 6600000 & 80000000 & 3000000 \\
\hline & $\operatorname{aopx}_{\text {It }}^{\top}$ & US\$ & 160000 & 340000 & 550000 & 7300000 & 230000 \\
\hline \multirow{4}{*}{ Transport line } & Lenght & $\mathrm{km}$ & 4 & 8 & 2 & 28 & 5 \\
\hline & $\operatorname{cap}_{\mathrm{i}}^{\mathrm{N}}$ & $\mathrm{M}^{3} / \mathrm{d}$ & 1750 & 3750 & 6000 & 100000 & 2500 \\
\hline & $\mathrm{cpx}_{\mathrm{i}}^{\mathrm{N}}$ & US\$ & 1000000 & 870000 & 2120000 & 22000000 & 1400000 \\
\hline & $\operatorname{aopx}_{i}^{N}$ & US\$ & 55000 & 43000 & 60000 & 500000 & 50000 \\
\hline Demand & $\mathrm{d}_{\mathrm{lh}}$ & $\mathrm{M}^{3} / \mathrm{d}$ & 1500 & 3300 & 5300 & 89000 & 2100 \\
\hline
\end{tabular}

Table 4. Model output decision variables

\begin{tabular}{|c|c|c|c|c|c|c|}
\hline Decision Variables & Unit & Hormoz & Sirik & Qeshm & Bandar Abbas & Abu Musa \\
\hline$x_{\text {lth }}$ & $\mathrm{m}^{3} / \mathrm{d}$ & 1500 & 3300 & 5300 & 89000 & 2100 \\
\hline$y_{\text {It }}$ & no & 1 & 1 & 1 & 1 & 1 \\
\hline $\mathrm{z}_{\text {ih }}$ & $\mathrm{m}^{3} / \mathrm{d}$ & 1500 & 3300 & 5300 & 89000 & 2100 \\
\hline$v_{1}^{c}$ & US\$ & 1949152.54 & 3813559.32 & 5593220.34 & 67796610.17 & 2542372.88 \\
\hline$c_{1}^{\top}$ & US\$ & 5421556.78 & 11464138.19 & 18118363.08 & 236489778.17 & 7468877.62 \\
\hline$w_{i}^{c}$ & US\$ & 847457.63 & 737288.14 & 1796610.17 & 18644067.80 & 1186440.68 \\
\hline $\mathrm{c}^{\mathrm{N}}{ }_{\mathrm{i}}$ & US\$ & 2024722.98 & 1682239.80 & 3120141.83 & 29756739.28 & 2235277.09 \\
\hline $\mathrm{u}_{1}^{\mathrm{cO} 2}$ & $\mathrm{Kg}$ & 1686300.00 & 3709860.00 & 5958260.00 & 100053800.00 & 2360820.00 \\
\hline $\mathrm{opxu}_{1}^{\mathrm{CO} 2}$ & US\$ & 968547.98 & 2130805.56 & 3422202.87 & 57467180.29 & 1355967.18 \\
\hline$C_{1}^{\text {redTDS\&chem }}$ & US\$ & 558744.03 & 1153166.96 & 1782612.10 & 22788547.36 & 756606.29 \\
\hline$c_{1}^{\text {envit }}$ & US\$ & 1527292.02 & 3283972.52 & 5204814.98 & 80255727.65 & 2112573.47 \\
\hline
\end{tabular}




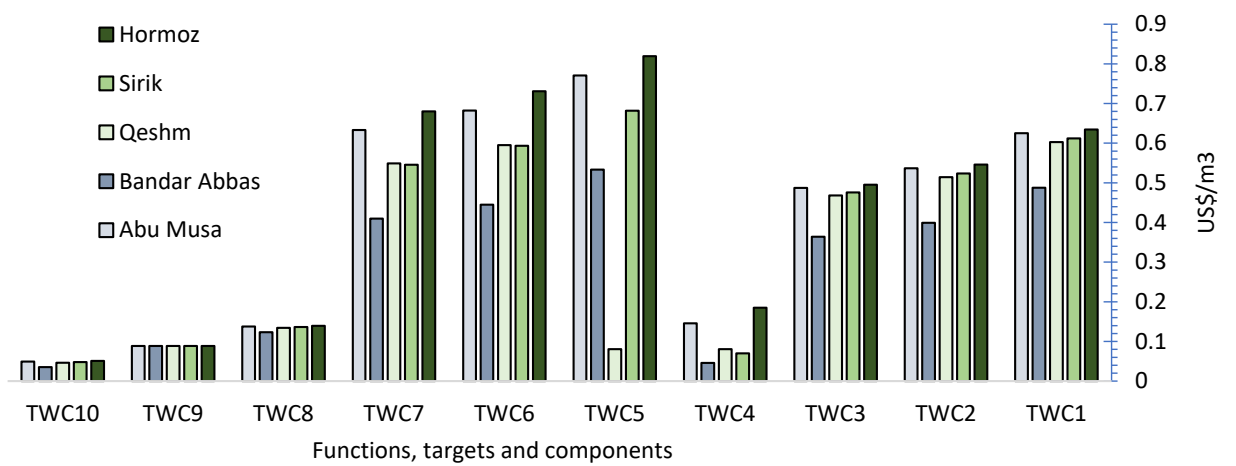

Figure 3. Comparative evaluation of the total cost of objective functions and their components in terms of cubic meters of freshwater.

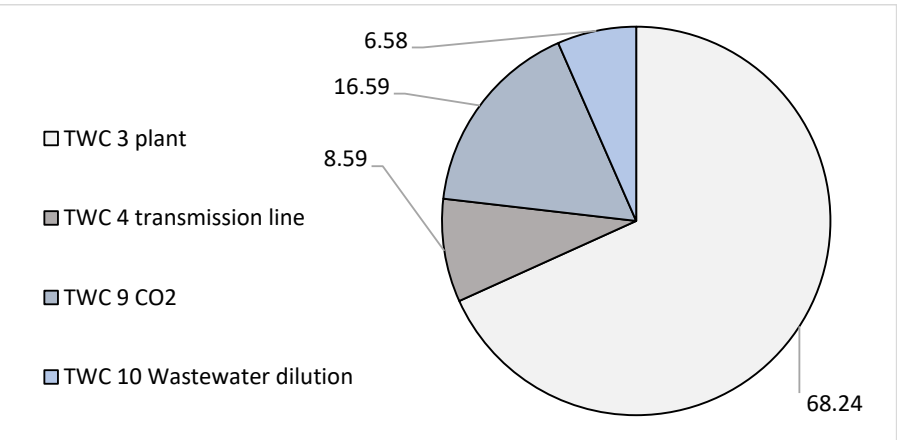

Figure 4. Supply chain cost $\left(\mathrm{US} \$ / \mathrm{m}^{3}\right)$ portion of environmental costs for water desalination in Hormozgan, Bandar abbas.

be reduced to some extent to descent $\mathrm{CO}_{2}$ emissions. However, the main solution is to use renewable energy instead of fossil fuels.

Dilution costs to reduce environmental impacts

The desalination plants use significant amounts of chemicals for the pre-treatment of saline and freshwater (25). Excessive salinity of effluent and discharge of large quantities of chemicals into coastal waters results in ecological imbalance and have major effects on receiving waters. To address environmental concerns related to effluent discharge into seawater, the concentration of chemicals and salts in the effluent should be reduced. The target function of "reducing environmental effects due to the effluent salinity" is transformed into a cost function. According to the Table 6 for dilution of different ratios of total dissolved solids (TDS) effluent to TDS receiving water, the percentages of the total cost of wastewater investment and total operating cost are estimated and entered into the model, the results of which are shown in Table 6. As shown in this table, the environmental goals are against environmental costs; hence, by higher costs, it can

Table 5. Relationship between the energy consumption and $\mathrm{CO}_{2}$ produced in the $100000 \mathrm{~m}^{3} / \mathrm{d}$ desalination plant in Bandar Abbas

\begin{tabular}{lccccc}
\hline Erlt $\left(\mathrm{kwh} / \mathrm{m}^{3}\right)$ & 2.0 & 2.5 & 3.0 & 3.5 & 4 \\
\hline $\mathrm{UI}_{\mathrm{CO} 2}\left(\mathrm{~kg} . \mathrm{CO}_{2}\right) /$ year & 50026900 & 62533625 & 74040350 & 87547075 & 100053800 \\
\hline
\end{tabular}

Table 6. Relationship between environmental impacts and costs

\begin{tabular}{lcccc}
\hline TDS effluent/(TDS receiving water & $\begin{array}{c}\text { Percentage of total investment } \\
\text { cost }\end{array}$ & $\begin{array}{c}\text { Percentage of total } \\
\text { operating cost }\end{array}$ & TWC 2 (US\$ $\left./ \mathbf{m}^{3}\right)$ & TWC 10 (US\$ $\left./ \mathbf{m}^{3}\right)$ \\
\hline 1.05 & 0.20 & 0.10 & 0.4126 & 0.0486 \\
1.10 & 0.15 & 0.07 & 0.3991 & 0.0351 \\
1.15 & 0.10 & 0.05 & 0.3883 & 0.0243 \\
1.20 & 0.07 & 0.03 & 0.3796 & 0.0156 \\
1.25 & 0.03 & 0.01 & 0.3699 & 0.0059 \\
\hline
\end{tabular}


meet better environmental quality related to desalination. More accurate cost estimates should be spent on a specific project and its local data. The cost of "wastewater management" is of great interest as the cost of wastewater disposal increases with the production of freshwater. The dilution cost (TWC 10) for the TDS of effluent to receiving water ratio is the US $\$ 0.0351 / \mathrm{m}^{3}$. The decision-maker can attract the attention of the environmental organization according to the cost and reduce the environmental impacts. In case the ratio of TDS effluent to TDS intake water is considered to be in the standard range of $1: 1$, the share of dilution costs will be $7.89 \%$, according to Figure 5.

To dilute the RBW in seawater, diffuser equipment is required, and to achieve a water flow rate of 5 to 8 meters per second, energy should be consumed. Depending on the site-specific conditions, discharge costs to the seafloor for dilution at sea are significant, typically accounting for 10 to $30 \%$ of the total investment costs of the desalination plants (26). Previously many researches focused on supply chain management coordination and optimization challenges in different industries and circumstances (27$30)$. Even some scholars considered environmental and social issues in their studies (31-33).

\section{Conclusion}

This study aimed to model optimization of strategic environmental management decisions in the operation of reverse osmosis desalination; emphasizing the costs required for environmental protection during the production of freshwater using reverse osmosis technology. Due to the relatively high costs of controlling environmental pollutants, unfortunately, many of these desalination plants remain neglected. The desalination plants of Abu Musa, Bandar Abbas, Qeshm, Sirik, and Hormoz with water production flow rate of 2100, 89000, 5300,3300 and 1500 can generate 2360.82, 100053.80, $5958.260,3709.86$ and 1686.30 tons of $\mathrm{CO}_{2}$ emissions per year respectively.

This environmental cost model can still be applied if we have access to in-sea effluent dilution technology. This type of wastewater dilution proposed in this study is such that wastewater is diluted before entering the seawater, only consuming higher energy than other methods and does not require sophisticated technology. Therefore, for Iran and the Middle East, where energy is cheaper than in other parts of the world, it can be used to reduce the environmental impact of wastewater. According to the obtained results it requires $1.35,57.47,3.42,2.13$ and 0.97 million USD for the control of the amounts of $\mathrm{CO}_{2}$ that mentioned above. For reduction of mal impacts of RBW, $0.75,22.79,1.78,1.15$ and 0.55 million USD respectively are required.

On the basis of the applied results of the model, to reduce the environmental impacts of effluent salinity it is recommended to dilute the desalination brine using

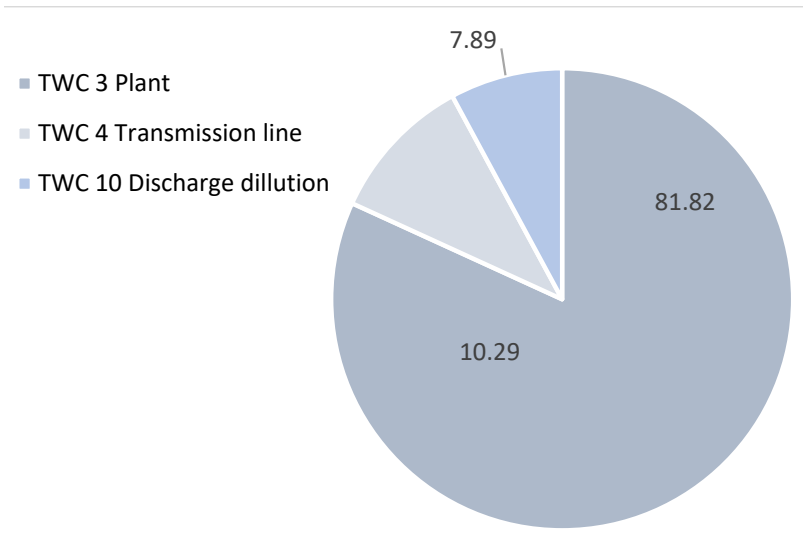

Figure 5. Costs percentage of supply chain sections including environmental costs only for wastewater dilution, without cost for $\mathrm{CO}_{2}$ control; for TWC 6 total $=0.4449$ US $\$ / \mathrm{m}^{3}$.

intake water before entering seawater for desalination up to $50000 \mathrm{~m}^{3} / \mathrm{d}$. Eventually for $100000 \mathrm{~m}^{3} / \mathrm{d}$ water desalination plants and power plants are combined in one place, meaning that using power plant cooling water to dilute the desalination effluent before entering the effluent into the seawater to save the dilution cost. As the pretreatment units are very important determinants in desalination costs, it is suggested that a study should be conducted to evaluate the effects of different pretreatment methods on desalination costs.

The limitations of this study were the non-inclusion of small components of investment and operating costs as well as the non-inclusion of the social dimension of sustainability in the mathematical model as it made the model more complicated.

\section{Acknowledgments}

This study is a part of a Ph.D. thesis (thesis code 2502268) in the field of Production and Operations Management, University of Tehran, Kish International Campus.

\section{Ethical issues}

The authors hereby certify that all data collected during the research areas expressed in the manuscript, and no data from the study has been or will be published elsewhere separately.

\section{Competing interests}

The authors declare that they have no conflicts of interest.

\section{Authors' contribution}

All authors were involved in data collection, analysis, and interpretation. All authors reviewed, refined, and approved the manuscript.

\section{References}

1. Balfaqih H, Nopiah ZM, Saibani N. A conceptual framework for supply chain performance in desalination industry. International Journal of Industrial Engineering 
and Management 2016; 7(2): 95-101.

2. Proskynitopoulou V, Katsoyiannis IA. Review of recent desalination developments for more efficient drinking water production across the world. New Materials, Compounds and Applications 2018; 2(3): 179-95.

3. Alipour V, Baneshi MM, Rahdar S, Narooie MR, Salimi A, Khaksefidi R, et al. Are household water purification devices useful to improve the physical chemical and microbial quality of the feed water? case study: Bandar Abbas south of Iran. International Journal of Tropical Medicine 2016; 11(6): 251-6.

4. Caldera U, Breyer C. Learning curve for seawater reverse osmosis desalination plants: capital cost trend of the past, present, and future. Water Resour Res 2017; 53(12): 10523-38. doi: 10.1002/2017wr021402.

5. Missimer TM, Maliva RG. Environmental issues in seawater reverse osmosis desalination: intakes and outfalls. Desalination 2018; 434: 198-215. doi: 10.1016/j. desal.2017.07.012.

6. Koleva MN, Calderón AJ, Zhang D, Styan CA, Papageorgiou LG. Integration of environmental aspects in modelling and optimisation of water supply chains. Sci Total Environ 2018; 636: 314-38. doi: 10.1016/j. scitotenv.2018.03.358.

7. Roberts DA, Johnston EL, Knott NA. Impacts of desalination plant discharges on the marine environment: a critical review of published studies. Water Res 2010; 44(18): 5117-28. doi: 10.1016/j.watres.2010.04.036.

8. Herrero-Gonzalez M, Admon N, Dominguez-Ramos A, Ibañez R, Wolfson A, Irabien A. Environmental sustainability assessment of seawater reverse osmosis brine valorization by means of electrodialysis with bipolar membranes. Environ Sci Pollut Res Int 2020; 27(2): 1256-66. doi: 10.1007/s11356-019-04788-w.

9. Höpner T, Windelberg J. Elements of environmental impact studies on coastal desalination plants. Desalination 1997; 108(1-3): 11-8. doi: 10.1016/S00119164(97)00003-9.

10. Gacia E, Invers O, Manzanera M, Ballesteros E, Romero J. Impact of the brine from a desalination plant on a shallow seagrass (Posidonia oceanica) meadow. Estuar Coast Shelf Sci 2007; 72(4): 579-90. doi: 10.1016/j. ecss.2006.11.021.

11. Ruso Ydel P, Carretero JA, Casalduero FG, Lizaso JL. Spatial and temporal changes in infaunal communities inhabiting soft-bottoms affected by brine discharge. Mar Environ Res 2007; 64(4): 492-503. doi: 10.1016/j. marenvres.2007.04.003.

12. Fernández-Torquemada Y, Sánchez-Lizaso JL, GonzálezCorrea JM. Preliminary results of the monitoring of the brine discharge produced by the SWRO desalination plant of Alicante (SE Spain). Desalination 2005; 182(13): 395-402. doi: 10.1016/j.desal.2005.03.023.

13. Shahabi MP, McHugh A, Anda M, Ho G. A framework for planning sustainable seawater desalination water supply. Sci Total Environ 2017; 575: 826-35. doi: 10.1016/j. scitotenv.2016.09.136.

14. Herrera-León S, Lucay F, Kraslawski A, Cisternas LA, Gálvez ED. Optimization approach to designing water supply systems in non-coastal areas suffering from water scarcity. Water Resour Manag 2018; 32(7): 2457-73. doi: 10.1007/s11269-018-1939-z.

15. Aliewi A, El-Sayed E, Akbar A, Hadi K, Al-Rashed M. Evaluation of desalination and other strategic management options using multi-criteria decision analysis in Kuwait. Desalination 2017; 413: 40-51. doi: 10.1016/j.desal.2017.03.006.

16. Bhojwani S, Topolski K, Mukherjee R, Sengupta D, ElHalwagi MM. Technology review and data analysis for cost assessment of water treatment systems. Sci Total Environ 2019; 651(Pt 2): 2749-61. doi: 10.1016/j. scitotenv.2018.09.363.

17. Al-Nory MT, Brodsky A, Bozkaya B, Graves SC. Desalination supply chain decision analysis and optimization. Desalination 2014; 347: 144-57. doi: 10.1016/j.desal.2014.05.037.

18. Balfaqih H, Al-Nory MT, Nopiah ZM, Saibani N. Environmental and economic performance assessment of desalination supply chain. Desalination 2017; 406: 2-9. doi: 10.1016/j.desal.2016.08.004.

19. Aleisa E, Al-Shayji K. Ecological-economic modeling to optimize a desalination policy: case study of an arid rentier state. Desalination 2018; 430: 64-73. doi: 10.1016/j.desal.2017.12.049.

20. Raluy G, Serra L, Uche J. Life cycle assessment of MSF, MED and RO desalination technologies. Energy 2006; 31(13): 2361-72. doi: 10.1016/j.energy.2006.02.005.

21. Karami S, Karami E, Zand-Parsa S. Environmental and economic appraisal of agricultural water desalination use in South Iran: a comparative study of tomato production. Journal of Applied Water Engineering and Research 2017; 5(2): 91-102. doi: 10.1080/23249676.2015.1105158.

22. Nisan S, Benzarti N. A comprehensive economic evaluation of integrated desalination systems using fossil fuelled and nuclear energies and including their environmental costs. Desalination 2008; 229(1-3): 12546. doi: 10.1016/j.desal.2007.07.031.

23. Kesieme UK, Milne N, Aral H, Cheng CY, Duke M. Economic analysis of desalination technologies in the context of carbon pricing, and opportunities for membrane distillation. Desalination 2013; 323: 66-74. doi: 10.1016/j.desal.2013.03.033.

24. Rezaei A, Naserbeagi A, Alahyarizadeh G, Aghaie M. Economic evaluation of Qeshm island MED-desalination plant coupling with different energy sources including fossils and nuclear power plants. Desalination 2017; 422: 101-12. doi: 10.1016/j.desal.2017.08.016.

25. Molinos-Senante M, González D. Evaluation of the economics of desalination by integrating greenhouse gas emission costs: An empirical application for Chile, Renewable Energy 2019; 133: 1327-37. doi.org/10.1016/j. renene.2018.09.019.

26. Voutchkov N. Overview of seawater concentrate disposal alternatives. Desalination 2011; 273(1): 205-19. doi 10.1016/j.desal.2010.10.018

27. Mahdiraji HA, Zavadskas EK, Razavi Hajiagha SH. Game theoretic approach for coordinating unlimited multi echelon supply chains. Transformations in Business \& Economics 2015; 14(2): 133-51.

28. Mahdiraji HA, Arabzadeh M, Ghaffari R. Supply chain 
quality management. Management Science Letters 2012; 2(7): 2463-72. doi: 10.5267/j.msl.2012.07.020.

29. Mahdiraji HA, Govindan K, Zavadskas EK, Razavi Hajiagha SH. Coalition or decentralization: a gametheoretic analysis of a three-echelon supply chain network. Journal of Business Economics and Management 2014; 15(3): 460-85. doi: 10.3846/16111699.2014.926289.

30. Jia P, Mahdiraji HA, Govindan K, Meidutè I. Leadership selection in an unlimited three-echelon supply chain. Journal of Business Economics and Management 2013; 14(3): 616-37. doi: 10.3846/16111699.2012.761648.

31. Asgharizadeh E, Lotfi M, Hosseinzadeh M, Mahdiraji HA, Salahshour S. Identification and ranking effective factors in increasing personnel satisfaction with intuitionistic fuzzy data in steel and rolling unit of Saba (Mobarakeh Steel Company). International Journal of Industrial Mathematics 2019; 12(1): 31-42.

32. Mahdiraji HA, Turskis Z, Jafarnejad A, Rezayar A. Noncooperative two-echelon supply chains with a focus on social responsibility. Technological and Economic Development of Economy 2019; 25(6): 1162-87. doi: 10.3846/tede.2019.10719.

33. Mahdiraji HA, Shateri H, Beheshti M, Mokhtarzadeh NG. A Comparison of Buyback, Rebate and Flexible Contracts in a Seller-Buyer Supply Chain. Transformations in Business \& Economics 2019; 18(1): 109-27. 